\title{
The Impact of Financial Performance and Audit Opinions: An Indonesian Case Study
}

\author{
Anna Sumaryati ${ }^{1, *}$, Foza Hadyu Hasanatina ${ }^{2}$, and Fanny \\ Fanny $^{3}$ \\ ${ }^{1,2}$ Dian Nuswantoro University, Semarang, Indonesia \\ ${ }^{3}$ Student of Dian Nuswantoro University, Semarang, Indonesia \\ anna.sumaryati@dsn.dinus.ac.id
}

\begin{abstract}
This study aims to analyze the impact of profitability, solvency, liquidity, firm size, and audit opinion on audit report lag. The population in this study are Property and Real Estate Enterprises registered on the Indonesian StockExchange for the 20172020 period. The sample selection in this study used the purposive sampling method, and the research sample obtained was 160 samples. The type and source of data used are secondary data. Based on multiple linear regression analyses using the SPSS 26.0 program, it was found that profitability and audit opinion had a significantly influence on audit report lag. Meanwhile, solvency, liquidity, size do not affect the lag of audit report. This research implies that real estate companies listed on the BEI, both large and small, are supervised by the government, capital supervisory agencies, investors, and the public. So, theyhave the same pressure to submit audited financial reports.
\end{abstract}

Keywords: Profitability, Audit Opinion, Audit Report Lag

\section{INTRODUCTION}

Financial statements are generated due to the accounting process and are used by stakeholders to determine the company's performance. It must be timely and possess certain quality qualities [7], [11]. The Financial Services Authority (FSA), as the regulatory body for financial services in Indonesia, establishes a deadline for public firms to submit financial reports following the end of the fourth month. For companies listed on the Indonesian Stock Exchange, timely financial reporting is required. External auditors' examinations of financial statements to determine the fairness of their presentation require an excessive amount of time. The time interval between the financial statements' reporting period and the independent auditor's report, which specifies the auditor's term to complete the audit, is referred to as the lag of the audit report. If financial information is not submitted on time, they lose their informational value, making decision-making more difficult for financial statement subscribers [2]. Delays in presenting audited financial accounts can result in information asymmetry, in which management have to access more information from shareholders, which they can utilize to boost their profits [2],[14],[12]. When presenting financial statements, timeliness is measured from the date the financial reports are closed until the auditor's report is completed. The period between the end of the financial statement book and the completion of the auditor's report is referred to as the Audit Report Lag. To collect audit evidence in the financial statements, the auditor must exercise caution when searching for audit evidence. The authors mentioned in [2] that Audit Report Lag (ARL) is a term that refers to an auditor's race to complete audit reports on time to audit financial statements [2]. In [3], the authors demonstrated that audit report latency is directly connected to the timeliness of earnings in publishing companies. The extended audit report lag affects the time required to deliver corporate profit information to investors and indicates worsening firm performance. The lower the audit report lag level of the enterprise, the faster the enterprise's financial information will be presented, and vice versa. Public accountants believe that public firms must disclose their yearly budgets and be backed by an audit opinion on the OJK. This is reinforced by the government's special laws, specifically Undang-undang No. 8 Tahun 1995 on the Capital Market, which requires all publicly traded businesses to submit periodic financial 
reports to the OJK and to make them publicly available. Public corporations have financial data that can be accounted for on all financial statement information. According to [1,] financial data is beneficial if it possesses three facets of value: predictive value, feedback, and timeliness. According to empirical studies, property and real estate companies faced an up and down cycle between 2016 and 2020 due to the company's delay in releasing audited financial accounts.

In 2016, one firm was late presenting its audited financial accounts for the fiscal year ended December 31,2015 . However, no company mentioned in the property and real estate business was late in presenting audited financial statements in 2017 based on financial reports as of December 31, 2016. Similarly, it was not too late in 2018. In 2019, there was another increase in the number of late companies. And by 2020, there will have been a dramatic increase to five corporations providing audited financial accounts late. One example of an Audit Report Lag that occurred in publicly traded property and real estate companies is PT. Cowell Development Tbk (COWL), where the Indonesian Stock Exchange's Director of Assessment stated that PT. Cowell Development did not publish financial information for the fiscal years ending December 31, 2019, and March 31, 2020. PT. Cowell Development is now undergoing bankruptcy proceedings. PT. Multi Cakra Kencana Abadi, as a creditor of PT. Cowell Development filed for bankruptcy protection on March 24, 2020, for a debt of Rp. 53.4 billion. The COWL case has resulted in the IDX suspending trading in shares of PT. Cowell Development since session II. Another example of an Audit Report Lag that occurred in publicly traded property and real estate companies is PT. Cowell Development Tbk (COWL), where the Indonesian Stock Exchange's Director of Assessment stated that PT. Cowell Development did not publish financial information for the fiscal years ending December 31, 2019, and March 31, 2020. PT. Cowell Development is now undergoing bankruptcy proceedings. PT. Multi Cakra Kencana Abadi, as a creditor of PT. Cowell Development filed for bankruptcy protection on March 24, 2020, for a debt of Rp. 53.4 billion. The COWL case has resulted in the IDX suspending trading in shares of PT. Cowell Development since trading session II [18]. The audit opinion contains information derived from a public accountant examining a company's financial statements to determine their fairness [24]. Financial statement fairness and reliability statements are usually issued after an independent audit process [25]. The audit opinion is formed due to the auditor's evaluation of the evidence gathered regarding the financial statements. In[7],[6],[26],[23], the authors investigated the relationship between profitability and the lag in audit report generation. Profitability affects audit report lag, according to these studies. Generally, [9] discovered that profitability does not affect audit report lag. Apart from profitability, audit report lags may be influenced by solvency. [7], [26], [23], and [1] investigate the relationship between solvency variables and the lag time associated with audit reports. These studies established that audit report lag is affected by solvency. On the other hand, [19] and [17] discovered the inverse, namely that the solvency variable did not affect audit report delay. Another factor believed to affect audit report lag is liquidity. In [23], the authors conducted correlation analyses between liquidity variables and audit report delays. Liquidity affects the audit report lag, as demonstrated by the findings. Otherwise, [9] research discovered the inverse relationship between the liquidity and audit report lag variables. In [7], the authors examined the relationship between firm size variables and the audit report lag. These studies discovered that firm size affects the audit report lag.

In contrast, in [14],[20], the authors have proven that firm size did not affect the lag of the audit report variable. Meanwhile, [17],[10], and [15] discovered that audit opinion did not affect the audit report's lag. There are still inconsistencies and conflicts in the research on audit report lag. As a result, a re-analysis is required to determine the impact of financial performance and audit opinion on the audit summary delay. The audit opinion contains information derived from the public accountant's assessment of the financial statements presented by the company in terms of their fairness [24]. Financial statement fairness and reliability statements are typically issued after an independent audit [25]. The auditor obtains the audit opinion following the auditor's evaluation of the financial statements. In 22], the authors established a link between audit opinion and audit report lag. These studies concluded that audit opinion affects audit report lag.

Our work aims to examine these relationships using a sample of property and real estate enterprises registered on the Indonesia Stock Exchange between 2017 and 2020. Property and real estate businesses offer considerable future potential for investors. It is evident from the potential to increase the number of residents, which will result in the construction of additional apartments, housing, and other structures. Correspondingly, the company continues to develop and grow year after year.

\section{LITERATURE REVIEW AND HYPOTHESES DEVELOPMENT}

\subsection{Profitability}

Return on Assets (ROA) is a profitability ratio calculated based on an organization's assets (Halim, 
2018). According to several studies, profitability affects the audit report lag [7], [3], [6], [2], [26], and [23]. In his research, he stated that ROA affects the audit report lag. Thus, hypothesis 1 is H1. ROA has a significant effect on the lag time between audit reports.

\subsection{Solvency}

The Debt Equity Ratio (DER) is a financial ratio used to determine a company's solvency [7]. Numerous studies [2], [26], [23], and [1] demonstrate that solvency affects the audit report lag. According to the Agency's theory, the principal will attempt to obtain a loan from the investor to keep the business running smoothly. On the other hand, investors will look to its operational processes for a return on their investment. Thus, hypothesis 2 is as follows:

H2. DER has a significant effect on the lag time between audit reports

\subsection{Liquidity}

The Current Ratio (CR) is a ratio used to determine liquidity [16]. Numerous studies [2] and [3] investigate the relationship between liquidity and audit report lag. Disclosure of information on a company's financial reports can help the company earn a favourable reputation among financial statement users. As a result, the agent makes a concerted effort to report his audited financial statements timely. Companies want to report their financial statements immediately following the previous closing period because this can result in positive news that boosts stock prices [2]. Thus, hypothesis 3 is as follows:

H3. CR has a significant impact on the time required to complete an audit report.

\subsection{Firm Dimensions}

The size of the business affects the amount of time required to complete the audit report. According to [21], [22], the size of a business can be influenced by the volume of transactions and the complexity of its operations. Large companies generally present their financial reports on time. They typically have the asset resources and appropriate technology to effectively manage all of their business operations, including their financial statements. [3],[2], [7], [16],[4], and [9] discovered that the size of the firm affects the audit report lag. Thus, hypothesis 4 is as follows:
H4. CR has a significant impact on the time required to complete an audit report.

\subsection{Opinion of the auditor}

An audit opinion is a statement issued by a certified public accountant that certifies the financial statements are fair. [3] stated that the auditor's objective in auditing a company's financial report is to express the auditor's opinion on the prevalence of material matters within the company after Indonesian accounting standards are implemented. Companies that have received unqualified audit opinions, investors, more value than companies deserving of opinions and disclaimer opinions. Companies that receive unqualified opinions can submit financial reports on time [15]. Meanwhile, companies that obtain unqualified opinions typically face a long delay in completing the audit report because the auditor may discover material errors in their financial statements. As a result, the auditor takes longer to complete the audit process of the financial statements. Audit opinion also affects the audit report [7] and [11], and research by [17], [10] indicates that audit opinion can affect the lag of the audit report. Thus, hypothesis 5 is as follows:

H5. The Audit Opinion has a sizable impact on the Audit Report Lag.

\section{RESEARCH METHOD}

The data processing tool uses the SPSS IBM SPSS-26 software version, which analyzes data using quantitative descriptive research methods [8]. The data source is annual financial reports published by the Indonesian Stock Exchange (IDX) from 2017 to 2020. Indeed, the purposive sampling is used in this study to obtain samples. This research sampled 160 businesses. The regression analysis technique was used in this study. In this vein, the proposed method aims to determine the effect of the ROA, DER, CR, Opini Audit, and Firm Size on the lag time between audit reports.

\section{RESULTS AND DISCUSSION}

As shown in Table 1 and Table 2, the first regression equation utilizes Audit Report Lag as the dependent variable:

Table 1. Results of Determination Coefficient Test

\begin{tabular}{|c|c|c|c|}
\hline \multicolumn{4}{|c|}{ Model Summary ${ }^{a}$} \\
\hline Model & $\mathrm{R}$ & R Square & Adjusted R Square \\
\hline 1 &, $771^{\mathrm{a}}$ & ,595 & ,581 \\
\hline $\mathrm{O}$ & $\begin{array}{l}\text { Predictors: (Consta } \\
\text { (X1),Solvency (X2 }\end{array}$ & n (X5), Firn & iquidity (X3), Profit \\
\hline $\mathrm{O}$ & Dependent Variabl & $\operatorname{ag}(\mathrm{Y})$ & \\
\hline
\end{tabular}


Table 2. Result of path analysis with Audit Report Lag as the dependent variable

\begin{tabular}{|c|c|c|c|c|c|}
\hline \multirow{4}{*}{$\overline{\text { Model } 1}$} & \multicolumn{4}{|c|}{ Coefficients $^{\mathrm{a}}$} & \multirow{4}{*}{ Sig } \\
\hline & \multicolumn{2}{|c|}{ Unstandardize } & \multirow{3}{*}{$\begin{array}{l}\text { Standardized } \\
\text { Beta }\end{array}$} & \multirow[t]{3}{*}{$\mathrm{t}$} & \\
\hline & B & Std & & & \\
\hline & & Error & & & \\
\hline$\overline{\text { Constant }}$ & 424,351 & 42,685 & & 9,390 &, 000 \\
\hline Profitabilitas & $-260,184$ & 43,500 &,- 309 & -5.981 & ,000 \\
\hline Solvabilitas & $-16,006$ & 11,255 &,- 077 & $-1,422$ & ,157 \\
\hline Likuiditas & ,039 &, 070 & -. 029 & ,562 & ,575 \\
\hline Size & $-2,208$ & 1,400 & -.085 & $-1,577$ & , 170 \\
\hline Opini Audit & $-257,036$ & 16,930 &,- 762 & $-15,182$ &, 000 \\
\hline
\end{tabular}

As shown in Table 2, the significance values for Preferabilities $(\mathbf{X 1})=\mathbf{0 . 0 0 0}$ and Opinion Audit $(\mathbf{X 5})=$ $\mathbf{0 , 0 0 0}$ are less than 0.05 . These findings indicate that ROA and Opini Audit significantly affect the time required to complete an audit report. As a result, H1 and $\mathbf{H 5}$ are accepted. While the significance values for Solvency (X2), Liquidity (X2), and Size (X2) are all greater than 0.05 , these results indicate that Solvability, Liquidity, and Firm Size all have a negligible effect on Audit Report Lag. As a result, H2, H3, and H4 are all rejected. The model's summary page indicates that the $\mathrm{R} 2$ value is 0.581 . This explains why the impact of profitability (ROA), solvency (DER), liquidity (CR), Audit Opinion, and Firm Size on Audit Report Lag is $58.1 \%$, while the remaining $41.9 \%$ is due to other variables not included in this study.

\section{CONCLUSION AND RECOMMENDATION}

Profitability and Audit Opinion both affect audit report lag. Profitability impacts the audit report's lag time because profitable businesses indicate profitable operations [3],[14]. Companies will complete financial statements more quickly if they contain positive news for financial statement users [15].

Due to an unqualified opinion resulting from a rushed audit process, audit opinion affects the lag time for the audit report. As a result, companies that receive views that are not unqualified tend to delay the public release of financial statements.

Solvency, liquidity, and firm size have no bearing on the lag time associated with an audit report. DER does not affect audit report lag, demonstrating that the debtto-equity ratio is not a factor in determining the speed with which financial statements are audited. Businesses with high and low liquidity levels desire timely publication of their financial statements. Thus, creditors can ascertain a business's ability to repay its debts. For creditors, the longer a company fails to submit financial statements, the more likely there is a problem.

The firm's size has no bearing on the audit report's delay [13], [6] stated that the Firm Size is considered with the PSPA (the Professional Standards of Public Accountants). Additionally, large and small public companies listed on IDX or the Indonesian Stock Exchange are regulated by the government, capital supervisory agencies, investors, and the general public. The public pressure to submit audited financial reports is likely to remain the same. The recommendation is to research non-property and real estate-related subjects and include more diverse independent variables.

\section{REFERENCES}

1. Artaningrum R G, Budiarto LK, \&Wirakusuma M.G (2017), The Effect of Profitability, Solvency, Liquidity, Company Size and Management Changes on the Audit Report Lag of Banking Companies. EJournal of Economic and Business of Udayana University 6 (3), 1079-1108

2. Ayuningtyas, Mi \& Riduwan,A (2020). Profitability, Liquidity, Solvency, Company Size andReputation of Public Accountants on Audit Report Lag. Journal of Accounting Science and Research 9(3), 1-21.

3. Knechel, W. and J. Payne. (2001), Additional Evidence on Audit Report Lag. Auditing: A Journal of Practice and Theory, 20(1), pp. 137-146.

4. Dura ,J (2017), The Effect of Profitability, Liquidity, Solvency and Company Size on Audit Report Lag in Companies listed on the Indonesia Stock Exchange, Scientific Journal of AsianBusiness and Economics, I (1), 64-70

5. Firmansyah, R, \& Amanah (2020), Effect of Profitability, Good Corporate Governance, Leverage and Firm Sixe on Audit Report Lag, Journal of Accounting Science and Research,9 (3), 1-30

6. Fitri A, Chomsatu Y, \& Dewi R,R (2020), The Effect of Financial Performance and Audit Opinion on Audit Report Lag in Banking Companies 2014-2017, Journal of Accounting Research and Computerized Accounting, I (2), 191-211

7. Harini, G, \& Siregar L,M (2020), The Effect of Profitability, Liquidity, Company Size and KAP Size 
on Audit Report Lag in State-Owned Enterprises Listed on the Indonesia Stock Exchange 2014-2017, Menara Ekonomi 17(1), 47-55

8. Hidayati N \& Hermanto S B (2018), The Influence of Company Size, Profitability, Audit Opinion, Type of Industry and Auditor's Reputation on Audit Report Lag, Journal of Accounting Science and Research, 7(7), 1-19.

9. Jensen, M.C, \& Meckling w, H.(1976), Theory of the Firm Managerian behavior, agency costand ownership structure, Journal of Fiancial Economocs, 3 (4), 305360 .

10. Metta, C, \& Effriyanti (2020), The Influence of Company Size, Public Ownership and Adoption of International Dinancial Reporting Standards (IFRS) on Audit Report Lag, Scientific Journal of Accounting.

11. Ningsih, A,C, \& Agustina Y (2019), The Influence of Audit Opinion, Auditor Change and Audience Profitability Lag in Retail Sector Companies Listed on the Indonesia StockExchange for the 2011-2018 period. Scientific Journal of Accounting.

12. Prasetyo, Y, Ahmar,N, \& Syam,m,MA (2020), Determinants of Audit Report Lag and the Role of Industry Specialization Auditors as Moderators in State-Owned Enterprises, Journalof Accounting and Taxation Research, 7(1).119-135.

13. Priantoko, Ni \& Herawati, V (2019), The Effect of Profitability, Solvency, Liquidity, Audit Opinion on Audit Lag Hassle with Audit Quality as Moderating Variable (Study on IDX Manufacturing Companies 2015-2016 period, Proceedings of the National Seminar of Scholars.

14. Salwa Febrianti, S (2020), The Effect of Profitability, Solvency and Audit Fee on Audit Report lag,
Diponegoro Journal of Accounting, 9(3), 2337-3806.

15. Sastrawan I,P \& latrine M,Y (2016), The Effect of Profitability, Solvency and Firm Size on Audit Report Lag in Manufacturing Companies. Udayana University Accounting E-Journal.

16. Shafie, Rohami \& Wan Hussin (2010), Corporate Governance and Audit report lag in Malaysia, AAMJAF, Vol 6, No.2, 57-84.

17. Susianto, S,N (2017). Effect of Mandatory Implementation of IFRS, Type of Industry, Loss, Subsidiaries, Size of KAP, Audit Opinion, and Size of Audit Committee on Audit Report Lag. Empirical Study on Companies Listed in BEO for the Period of 2009-2013, Accountingand Business Journal, 15 (1), 152-178.

18. Tampubolon RR \& Siagian V (2020), The effect of profitability, solvency, liquidity and audit tenure on audit report lag with the committee as moderating, Journal of Modernization Economics, 16 (2), 82-95.

19. Verawati, N.MA., \& Wirakusuma, M,G (2016), Effect of Auditor Change, Head Reputation,Audit Opinion, and Audit Committee on Audit Delay, Udayana University Accounting E- Journal, 17(2), 1083-1111.

20. Tiono I \& Jogi, Y (2018)., Factors Affecting Auditor Report Lag Period 2013-2016 on the Indonesia Stock Exchange. Journal of Estuary of Economics and Business, 2(1), 54. https://doi.org/10.24912/jmieb.v2i1.1655.

21. Yunita, N.M.Y, Adnantara,. K. F. \& Kusumadewi T (2020). The Effect of Profitability, Solvency, and Company Size on Audit Report Lag in Manufacturing Companies listed on the Indonesia Stock Exchange for the 2016-2018 Period. Journal of Research Accounting 02 (1),83-92. 